\title{
Comparison study between NPWM and NSVPWM strategy in FSMC control of stator reactive and active powers control of a DFIG-based wind turbine system
}

\author{
Habib Benbouhenni ${ }^{1}$, Zinelaabidine Boudjema ${ }^{2}$, Abdelkader Belaidi $^{3}$ \\ ${ }^{1,3}$ Labo. LAAS, Department of Electrical Engineering, National Polytechnique School of Oran Maurice Audin, Algeria \\ ${ }^{2}$ Labo. LGEER, Department of Electrical Engineering, Hassiba Benbouali University, Algeria
}

\begin{tabular}{l}
\hline Article Info \\
\hline Article history: \\
Received May 28, 2019 \\
Revised Jan 22, 2020 \\
Accepted Mar 10, 2020 \\
\hline
\end{tabular}

Keywords:

DFIG

FSMC

NPWM

NSVPWM

WECSs

\begin{abstract}
In this work, we present a comparative study between neural space vector pulse width modulation (NSVPWM) and neural pulse width modulation (NPWM) technique in fuzzy-sliding mode control (FSMC) of stator active and stator reactive power control of a doubly fed induction generator (DFIG) for wind energy conversion systems (WECSs). Two strategies approach using FSMC-NSVPWM and FSMC-NPWM are proposed and compared. The validity of the proposed strategies is verified by simulation tests of a DFIG (1.5MW). The reactive power, electromagnetic torque, rotor current and stator active power is determined and compared in the above strategies. The obtained results showed that the proposed FSMC with NSVPWM strategy has stator reactive and active power with low powers ripples and low rotor current harmonic distortion than NPWM strategy.
\end{abstract}

This is an open access article under the CC BY-SA license.

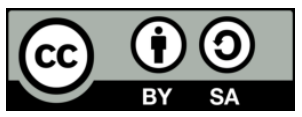

Corresponding Author:

Habib Benbouhenni,

Labo. LAAS, Department of Electrical Engineering,

National Polytechnique School of Oran Maurice Audin, Oran, Algeria.

Email: habib0264@gmail.com

\section{INTRODUCTION}

Traditionally, pulse width modulation (PWM) is most popular technique used in the AC machine drives. The PWM strategy is simple and easy to implement [1]. But, this technique gives more total harmonic distortion (THD) of current and voltage output [2]. This strategy is unable to fully utilize the available DC bus supply voltage to the VSI [3]. In order to overcome the drawbacks of the traditional PWM technique, space vector pulse width modulation (SVPWM) strategy has been presented [4-6]. This strategy based on the principles of space vectors and need to calculate of angle and sector [7]. This strategy gives 15\% more voltage output compare to the conventional PWM method, thereby increasing the DC bus utilization [8]. On the other hand, this strategy reduces the THD value of current/voltage compared to the PWM strategy.

In [9], the author has proposed a new SVPWM strategy, this strategy based on calculating minimum (Min) and maximum (Max) of three-phase voltages. SVPWM and artificial neural networks (ANNs) controller are combined to control DFIG-based wind turbine [10]. Fuzzy SVPWM (FSVPWM) is proposed to regulate the stator reactive and active power of the DFIG [11]. In [12], a reactive and active power proportional-integral (PI) controllers and three-level FSVPWM strategy were combined to regulate the electromagnetic torque and current of the DFIG. In [13], a three-level neural SVPWM strategy of a DFIG was presented. In [14], four-level SVPWM based on FLC control to regulate the active and reactive power of the DFIG.

Field oriented control (FOC) using PI controllers are the traditional strategy used for DFIG. In [15], FOC control is the most popular technique used in the DFIG-based wind energy conversion system. 
The FOC is simple and easy to implement [16]. In this strategy the decoupling q-axis and d-axis current is achieved with feed forward compensation, and thus the DFIG model becomes less difficult and PI regulators can be used [17]. On the other hand, this strategy gives more THD value of stator current/voltage and electromagnetic torque ripples [18].

For robust and high performances FOC, a sliding mode controller (SMC) was studied in the literature [19-21]. SMC based on theory of variable structure systems (VSS) has been extensively employed for nonlinear systems [22]. It is an effective, high frequency switching control strategy for nonlinear systems with uncertainties. It can offer many good properties such as good performances against unmodeled dynamics, insensitivity to parameters variation, external disturbance rejection and fast dynamic response [23]. A neural sliding mode controller (NSMC) is to control the DFIG [24]. A discrete SMC is designed to regulate the real and reactive power of DFIG [25]. In [26], an integral SMC control was designed to regulate the stator reactive power and electromagnetic torque. In this paper, we apply the FSMC control to the DFIG using the NPWM strategy and compared with the NSVPWM strategy.

\section{MODELING OF THE DFIG}

A model of the DFIG is presented in literature [27, 28]. In the Park reference frame, the rotor and stator voltage equations of the DFIG are given as follows:

$$
\left\{\begin{array}{l}
\mathrm{V}_{\mathrm{ds}}=\mathrm{R}_{\mathrm{s}} \mathrm{I}_{\mathrm{ds}}+\frac{\mathrm{d}}{\mathrm{dt}} \psi_{\mathrm{ds}}-\omega_{\mathrm{s}} \psi_{\mathrm{qs}} \\
\mathrm{V}_{\mathrm{qs}}=\mathrm{R}_{\mathrm{s}} \mathrm{I}_{\mathrm{qs}}+\frac{\mathrm{d}}{\mathrm{dt}} \psi_{\mathrm{qs}}+\omega_{\mathrm{s}} \psi_{\mathrm{ds}} \\
\mathrm{V}_{\mathrm{dr}}=\mathrm{R}_{\mathrm{r}} \mathrm{I}_{\mathrm{dr}}+\frac{\mathrm{d}}{\mathrm{dt}} \psi_{\mathrm{dr}}-\omega_{\mathrm{r}} \psi_{\mathrm{qr}} \\
\mathrm{V}_{\mathrm{qr}}=\mathrm{R}_{\mathrm{r}} \mathrm{I}_{\mathrm{qr}}+\frac{\mathrm{d}}{\mathrm{dt}} \psi_{\mathrm{qr}}+\omega_{\mathrm{r}} \psi_{\mathrm{dr}}
\end{array}\right.
$$

The rotor and stator fluxes equations are given as follows:

$$
\left\{\begin{array}{l}
\psi_{d s}=L_{s} I_{d s}+M I_{d r} \\
\psi_{q s}=L_{s} I_{q s}+M I_{q r} \\
\psi_{d r}=L_{r} I_{d r}+M I_{d s} \\
\psi_{q r}=L_{r} I_{q r}+M I_{q s}
\end{array}\right.
$$

The electromagnetic torque can be expressed as:

$$
T_{e}=p M\left(I_{d r} \cdot I_{q s}-I_{q r} . I_{d s}\right)
$$

The electromagnetic torque in the mechanical equation of the DFIG is defined as follows:

$$
T_{e}=T_{r}+J \cdot \frac{d \Omega}{d t}+f \cdot \Omega
$$

The stator active and stator reactive powers can be expressed as:

$$
\left\{\begin{array}{l}
P_{s}=\frac{3}{2}\left(V_{d s} I_{d s}+V_{q s} I_{q s}\right) \\
Q_{s}=\frac{3}{2}\left(V_{q s} I_{d s}-V_{d s} I_{q s}\right)
\end{array}\right.
$$




$\begin{array}{ll}\text { where: } R_{r} & : \text { Resistances of the rotor windings } \\ R_{s} & : \text { Resistances of the stator windings } \\ T_{r} & : \text { Load torque } \\ V_{d r}, \text { and } V_{q r} & : \text { Rotor voltages } \\ V_{q s} \text { and } V_{d s} & : \text { Stator voltages } \\ I_{d r}, \text { and } I_{q r} & : \text { Rotor currents } \\ I_{d s} \text { and } I_{q s} & : \text { Stator currents } \\ \psi_{d r} \text { and } \psi_{q r} & : \text { Rotor fluxes } \\ \psi_{d s} \text { and } \psi_{q s} & : \text { Stator fluxes } \\ L_{r} & : \text { Inductance own rotor } \\ L_{s} & : \text { Inductance own rotor } \\ M & : \text { Mutual inductance } \\ T_{e} & : \text { Electromagnetic torque } \\ \omega_{s} & : \text { Electrical pulsation of the stator } \\ \omega_{r} & : \text { Electrical pulsation of the rotor } \\ \Omega & : \text { Mechanical rotor speed } \\ P_{s} & : \text { Stator active power } \\ Q_{s} & : \text { Stator reactive power } \\ J & : \text { Inertia } \\ f & : \text { Viscous friction coefficient } \\ p & : \text { Number of pole pairs }\end{array}$

\section{NEURAL PULSE WIDTH MODULATION}

Using the traditional PWM strategy provides many advantages, such as simple modulation and easy implementation. On the other hand, the major problem of the traditional PWM strategy is the harmonic distortion of voltage and current caused by the hysteresis comparators. The traditional PWM strategy designed to control the two-level inverter is illustrated in Figure 1.

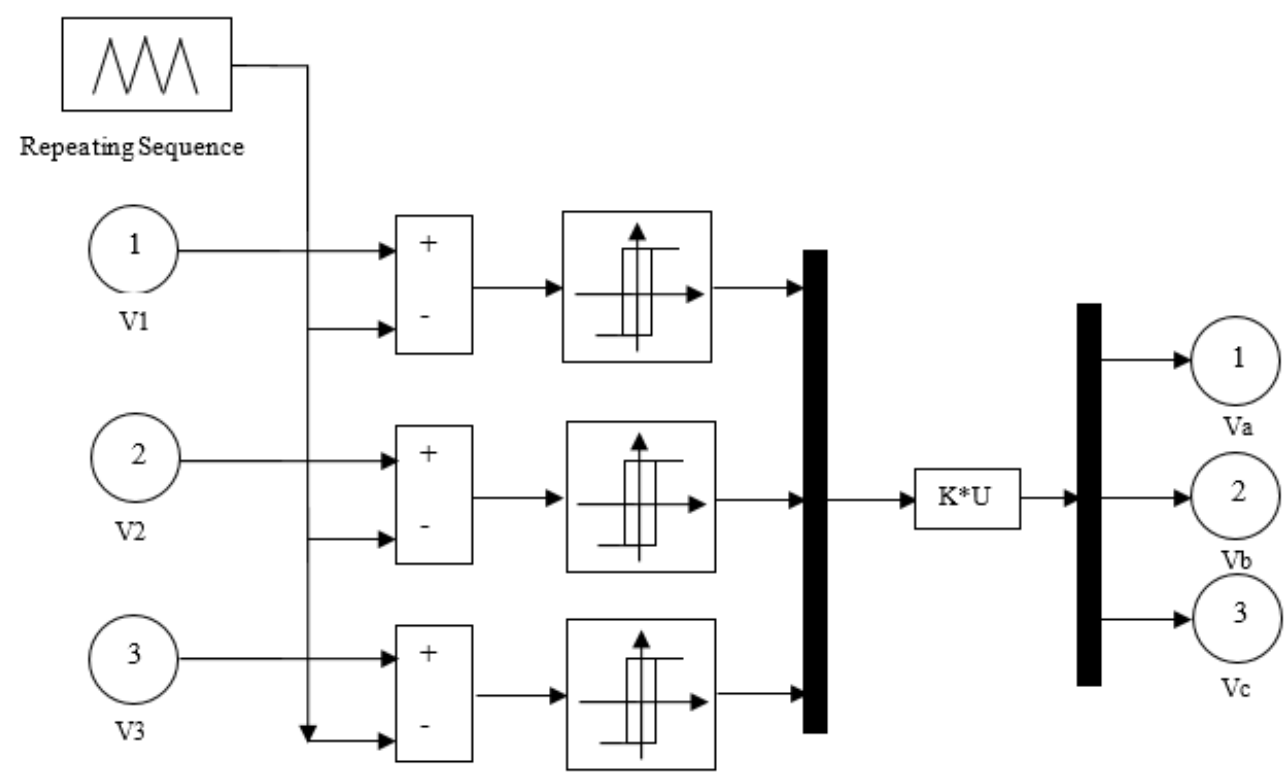

Figure 1. Conventional PWM technique

To reduce the harmonic distortion of stator current and voltages of DFIG, we have applied the NPWM strategy. The principle of the NPWM strategy is similar to traditional PWM strategy. The difference results in using a neural networks controller to replace the hysteresis comparators. As shown in Figure 2. This strategy is simple modulation scheme and easy to implement. This proposed strategy reduces the harmonic distortion of stator current and gives minimum power ripples of the DFIG-based wind turbine. 


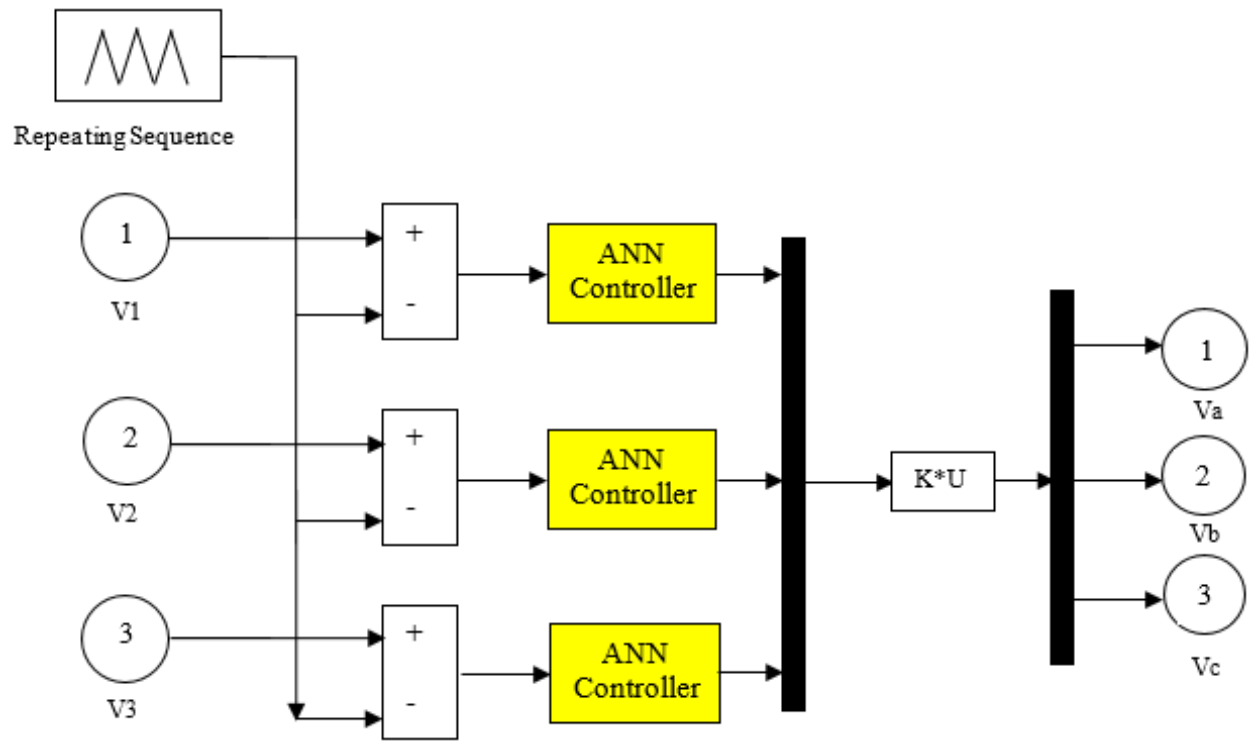

Figure 2. NPWM technique

The training used is that of the algorithm, gradient descent with momentum and adaptive LR (ALR). The convergence of the network in summer obtained by using the value of the parameters grouped in Table 1. The block diagram of the ANN controllers is shown in Figure 3. The construction of layer 1 and layer 2 is shown in Figures 4 and 5 respectively.

Table 1. Parameters of the ALR algorithm

\begin{tabular}{ll}
\hline Parameters of the LM & Values \\
\hline Number of hidden layer & 10 \\
TrainParam.Lr & 0.005 \\
TrainParam.show & 50 \\
TrainParam.eposh & 1000 \\
Coeff of acceleration of convergence $(\mathrm{mc})$ & 0.9 \\
TrainParam.goal & 0 \\
TrainParam.mu & 0.9 \\
Functions of activation & Tensing, purling, gensim \\
\hline
\end{tabular}

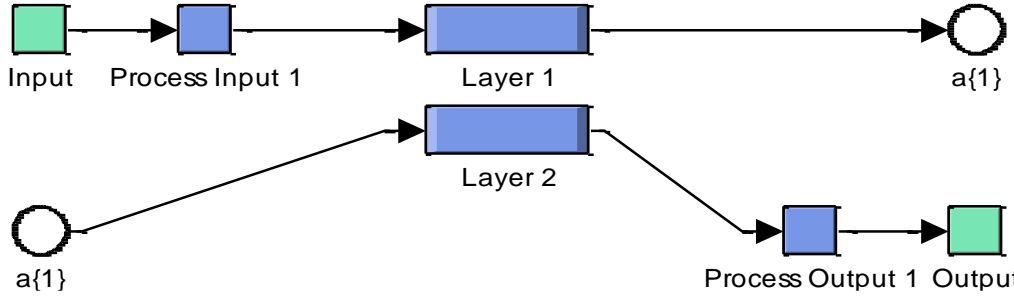

Figure 3. Block diagram of the ANN controllers

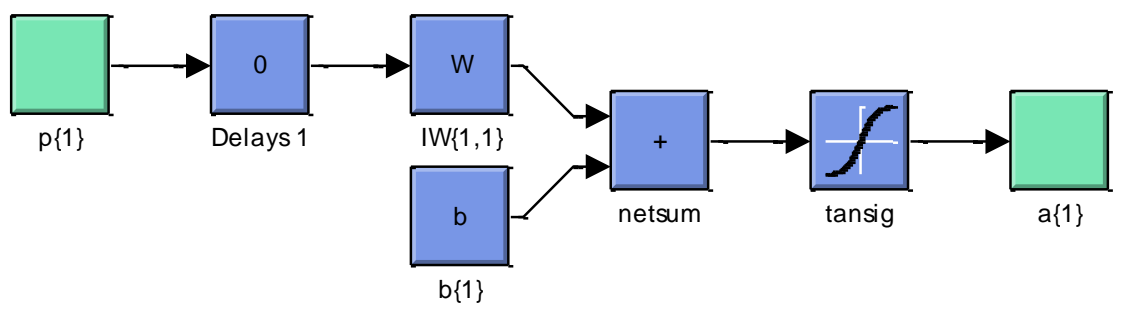

Figure 4. Layer 1 


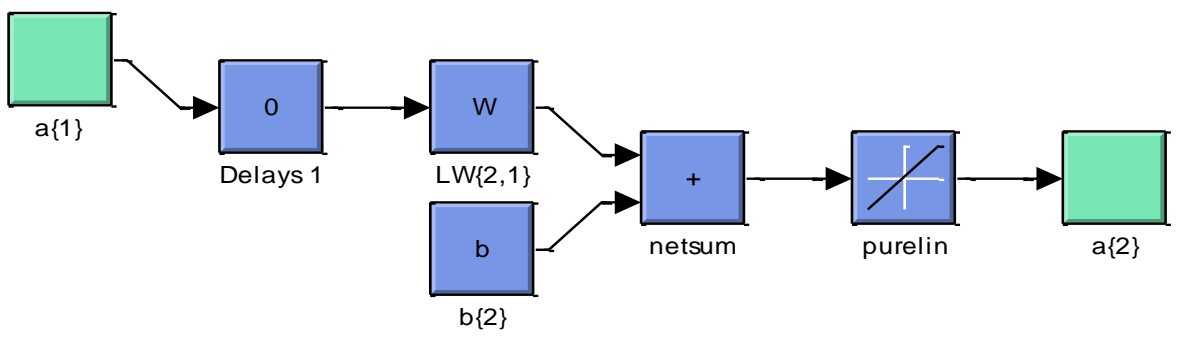

Figure 5. Layer 2

\section{NEURAL SPACE VECTOR PULSE WIDTH MODULATION}

Figure 6 show the principle of the two-level SVPWM strategy. This strategy based on calculating minimum and maximum of three-phase voltages [29]. This strategy not needed to calculated of the angle and sector compared with traditional SVPWM technique. This strategy is detailed in [30]. On the other hand, this strategy is simple and easy to implement compared to conventional SVPWM technique. The block diagram of the hysteresis comparators is shown in Figure 7. The principle disadvantages of the SVPWM strategy is that the harmonic distortion of stator current and voltages. In order to overcome the drawbacks of the SVPWM strategy a complimentary use of the ANN controller is proposed. However, the ANN controller contains a hidden layer, input layer and output layer [31]. Recent years, ANN controller has found many applications such as control AC machines.

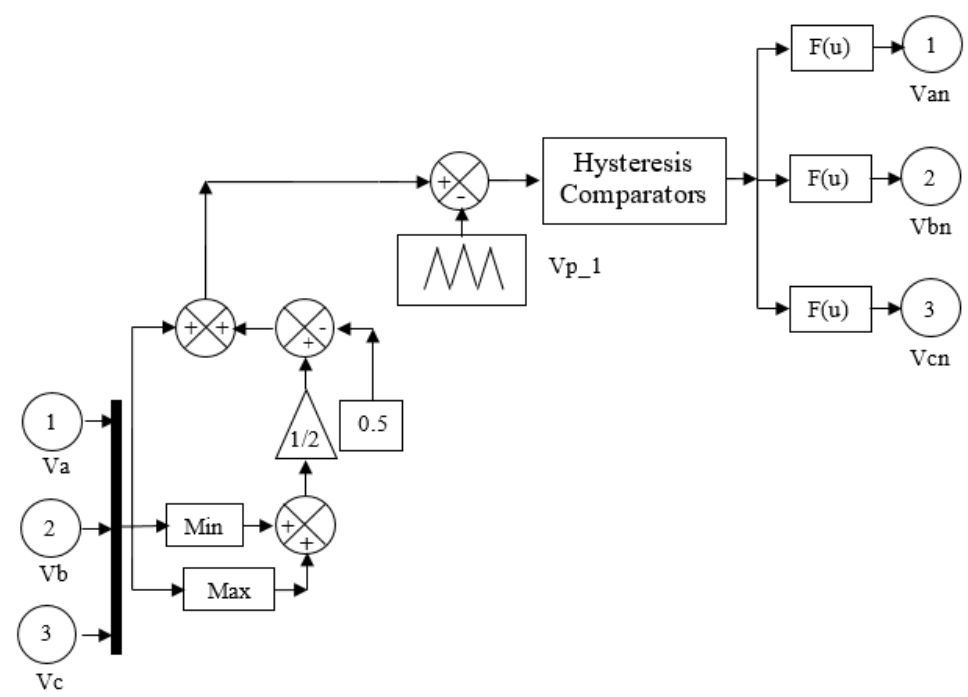

Figure 6. Block diagram of two-level SVPWM strategy

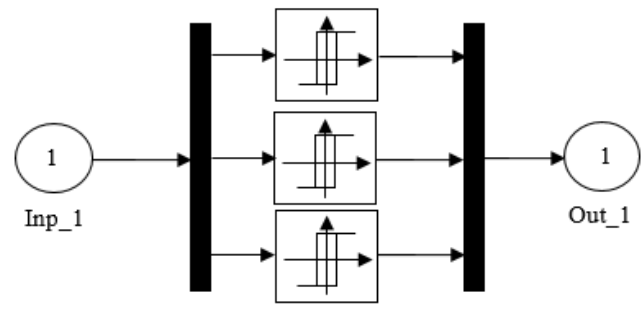

Figure 7. Block diagram of hysteresis comparators

ANN as one of the nonlinear methods proved their superiority over linear method for making a calibration model [32]. The principle of the two-level NSVPWM technique is similar to two-level SVPWM strategy. The difference results in using the ANN controllers to replace the hysteresis comparators [29].

Comparison study between NPWM and NSVPWM strategy in FSMC control of... (Habib Benbouhenni) 
As shown in Figure 8. This proposed strategy is simple control and easy to implement. This proposed strategy reduces the harmonic distortion of stator current and voltages. The training used is that of the retro propagation of Levenberg-Marquardt (LM). The parameters of the LM algorithm are shown in Table 2, the block diagram of the neural hysteresis comparators is shown in Figure 9, and the block diagram of the ANN controllers is shown in Figure 10.

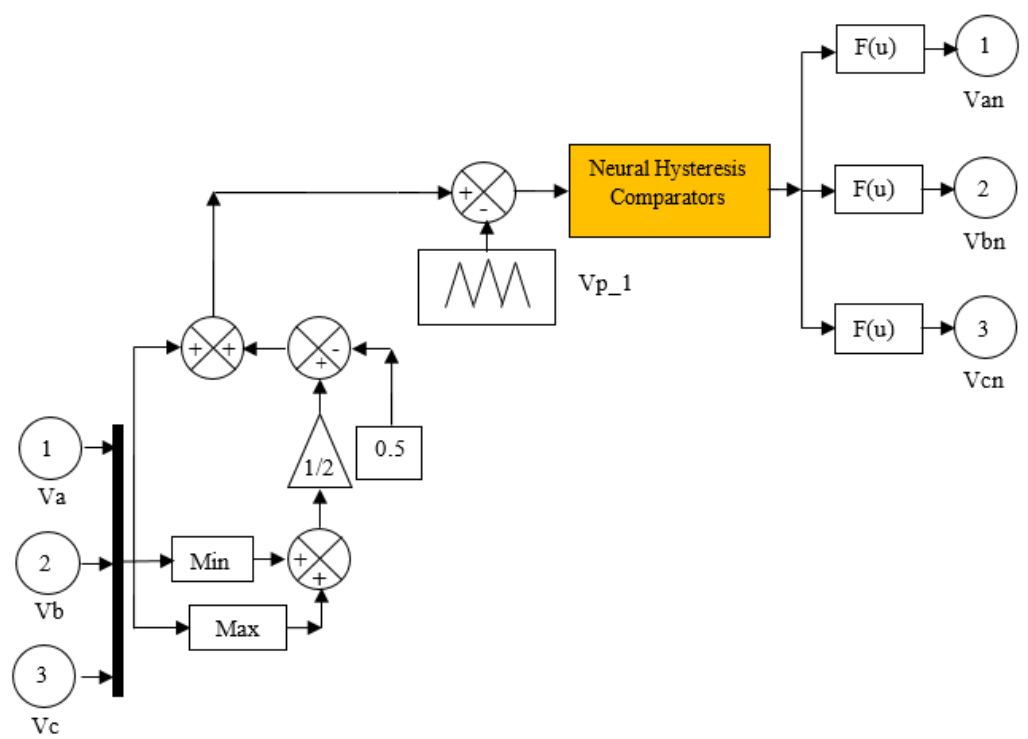

Figure 8. Block diagram of two-level NSVPWM strategy

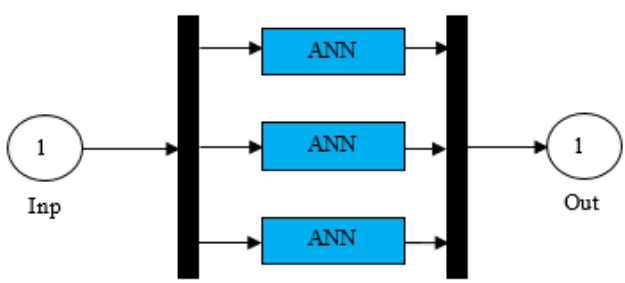

Figure 9. Block diagram of neural hysteresis comparators

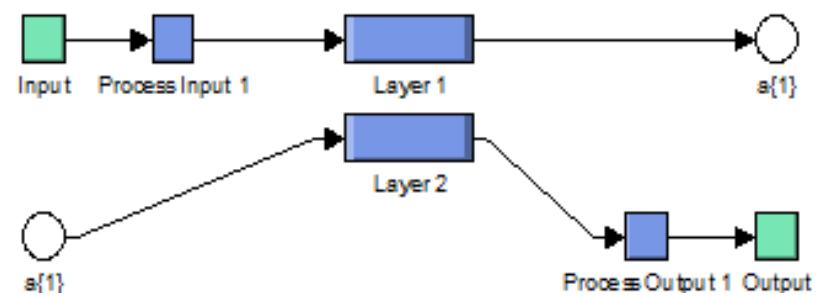

Figure 10. Block diagram of ANN controllers

Table 2. Parameters of the LM algorithm

\begin{tabular}{ll}
\hline Parameters & Values \\
\hline Number of hidden layer & 8 \\
TrainParam.Lr & 0.002 \\
TrainParam.show & 50 \\
TrainParam.eposh & 300 \\
Coeff of acceleration of convergence $(\mathrm{mc})$ & 0.9 \\
TrainParam.goal & 0 \\
TrainParam.mu & 0.9 \\
Functions of activation & Tensing, purling, gensim \\
\hline
\end{tabular}




\section{FUZZY SLIDING MODE CONTROL}

Sliding mode control is one of the most popular control in use nowadays. This strategy control based on theory of variable structure systems [33]. This strategy was proposed by Utkin in 1977 [34]. However, the SMC is a strategy to adjust feedback by previously defining a surface. Since the robustness is the best advantage of the SMC control, it has been widely employed to control nonlinear systems that have model uncertainty and external disturbance [35]. On the other hand, the principle disadvantages of the SMC technique is that the chattering effect created by the discontinuous part of control [36].

Fuzzy logic is a technique based on engineering experience and observations. In FLC, an exact mathematical model is not necessary because linguistic variables are used to divine system behavior rapidly [37]. On way to improve SMC performance is to combine it with FLC controller to form a FSMC strategy. The design of a SMC incorporating FLC control helps in achieving minimized chattering, reduces the harmonic distortion of stator current, simple rule base, and robustness against disturbances and nonlinearities. The FSMC strategy is a modification of the SMC technique, where the switching controller term Sat $(\mathrm{S}(\mathrm{x}))$, has been replaced by a FLC control input as given by (6).

$$
V_{d q}^{c o m}=V_{d q}^{e q}+V_{d q}^{F u z z y}
$$

The proposed FSMC control with NSVPWM strategy, which is designed to control the stator reactive and stator active powers of the DFIG-based WTSs, is shown in Figure 11. The internal structure of FSMC control is shown in Figure 12. Membership functions in triangular shape are shown in Figure 13. The rule bases of the FSMC control are shown in the Table 3. The properties of our controller are given in the Table 4. The block diagram of the FLC is illustrated in Figure 14.

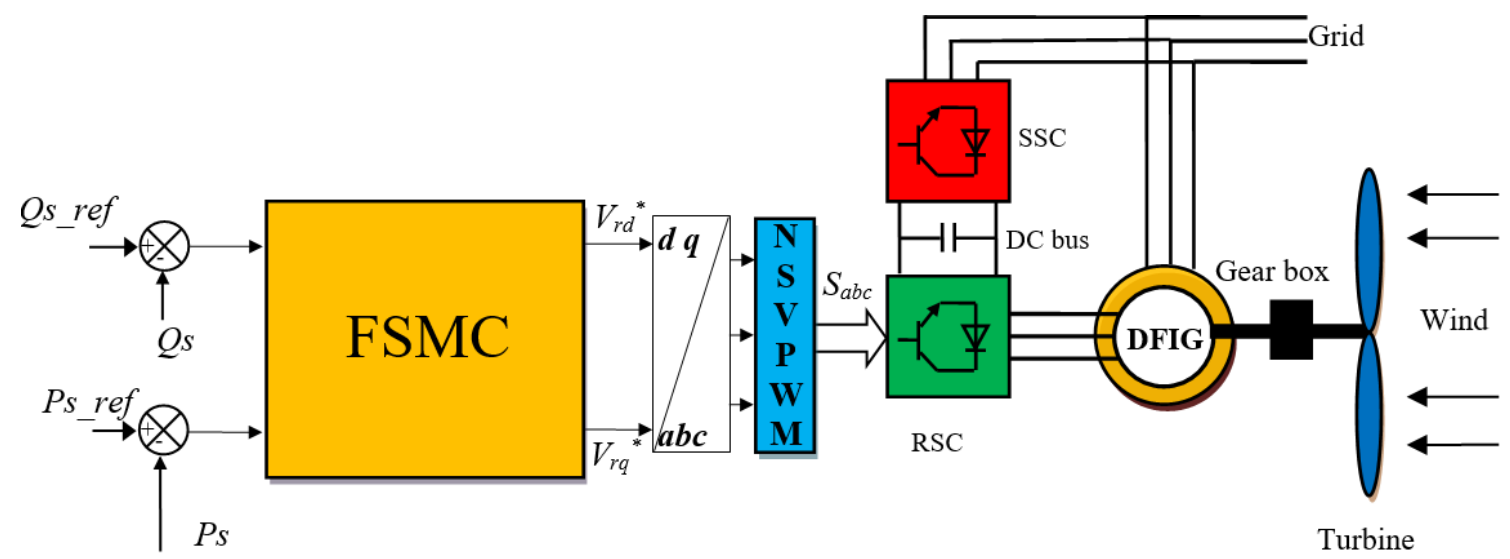

Figure 11. FSMC control of a DFIG using NSVPWM strategy

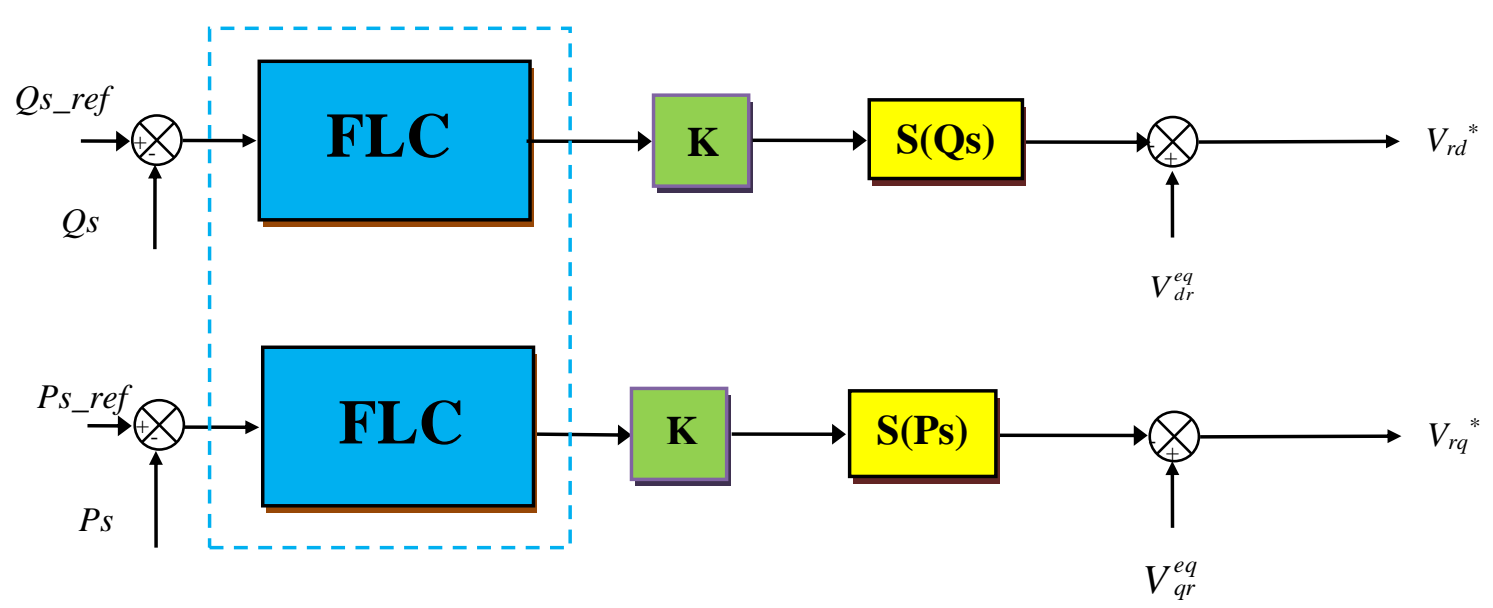

Figure 12. Block diagram of FSMC strategy 


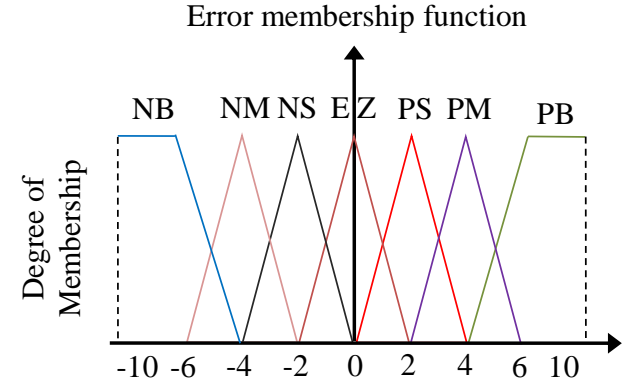

(a)

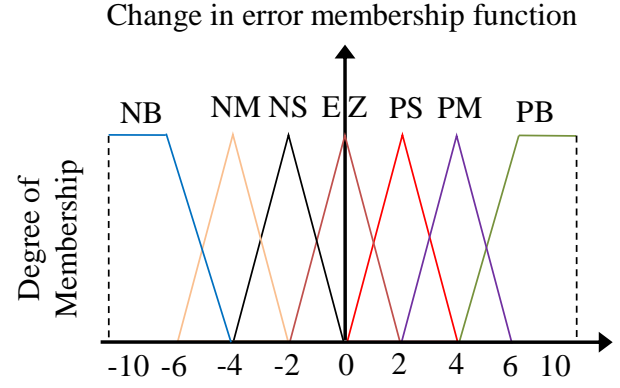

(b)

Figure 13. Membership functions, (a) Error membership function, (b) Change in error membership function

Table 3. FL rules

\begin{tabular}{|c|c|c|c|c|c|c|c|}
\hline $\begin{array}{l}\mathrm{e} \\
\Delta \mathrm{e}\end{array}$ & NB & NM & NS & EZ & PS & $\mathrm{PM}$ & $\mathrm{PB}$ \\
\hline $\mathrm{NB}$ & $\mathrm{NB}$ & NB & $\mathrm{NB}$ & NB & $\mathrm{NM}$ & NS & EZ \\
\hline $\mathrm{NM}$ & NB & NB & NB & NM & NS & EZ & PS \\
\hline NS & NB & NB & NM & NS & EZ & PS & PM \\
\hline EZ & NB & NM & NS & EZ & PS & PM & $\mathrm{PB}$ \\
\hline PS & $\mathrm{NM}$ & NS & EZ & PS & PM & PB & PB \\
\hline PM & NS & EZ & PS & PM & PB & PB & PB \\
\hline $\mathrm{PB}$ & EZ & PS & PM & PB & PB & PB & $\mathrm{PB}$ \\
\hline
\end{tabular}

Table 4. Parameters of FL

\begin{tabular}{ll}
\hline Fis type & Mamdani \\
\hline And method & Min \\
Or method & Max \\
Implication & Min \\
Aggregation & Max \\
Defuzzification & Centroid \\
\hline
\end{tabular}

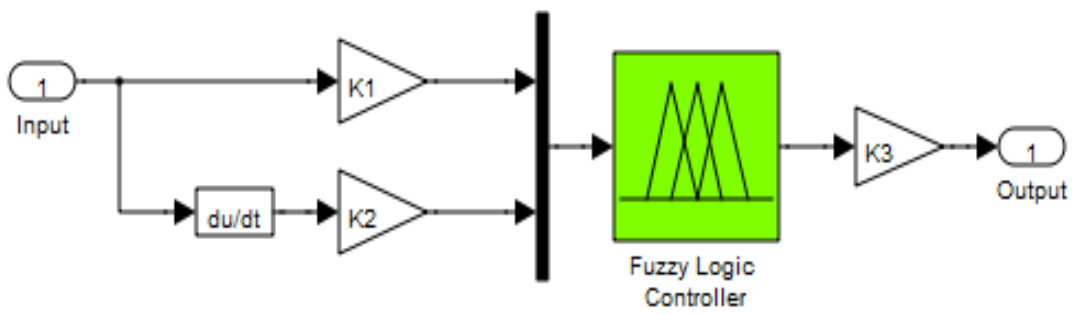

Figure 14. Block diagram of the FLC

\section{RESULTS AND DISCUSSION}

Simulations of the proposed control techniques for a DFIG-based wind turbine are conducted by using the MATLAB/Simulink software. The DFIG is rated at 1.5 MW and its parameters are listed in Table 5. The parameters of the proposed FSMC control are selected to provide optimum performance as $\mathrm{K}_{1}=0.0003$, $\mathrm{K}_{2}=0.00005$, and $\mathrm{K}_{3}=0.02$. The proposed FSMC control with two-level NPWM technique, which is designed to control the DFIG-based WTSs, is shown in Figure 15. The proposed strategies will be tested and compared in two different configurations: robustness against parameters variations and reference tracking.

Table 5. Parameters of the simulated DFIG

\begin{tabular}{ll}
\hline Parameter & Value \\
\hline $\mathrm{Pn}$ & $1.5 \mathrm{MW}$ \\
$\mathrm{Vn}$ & $380 \mathrm{~V}$ \\
$\mathrm{p}$ & 2 \\
$\mathrm{Rs}$ & $0.012 \Omega$ \\
$\mathrm{Rr}$ & $0.021 \Omega$ \\
$\mathrm{Ls}$ & $0.0137 \mathrm{H}$ \\
$\mathrm{Lr}$ & $0.0136 \mathrm{H}$ \\
$\mathrm{Lm}$ & $0.0135 \mathrm{H}$ \\
$\mathrm{J}$ & $1000 \mathrm{Kg} \cdot \mathrm{m} 2$ \\
$\mathrm{fr}$ & $0.0024 \mathrm{Nm} \cdot \mathrm{s} / \mathrm{rad}$ \\
$\mathrm{f}$ & $50 \mathrm{~Hz}$ \\
\hline
\end{tabular}




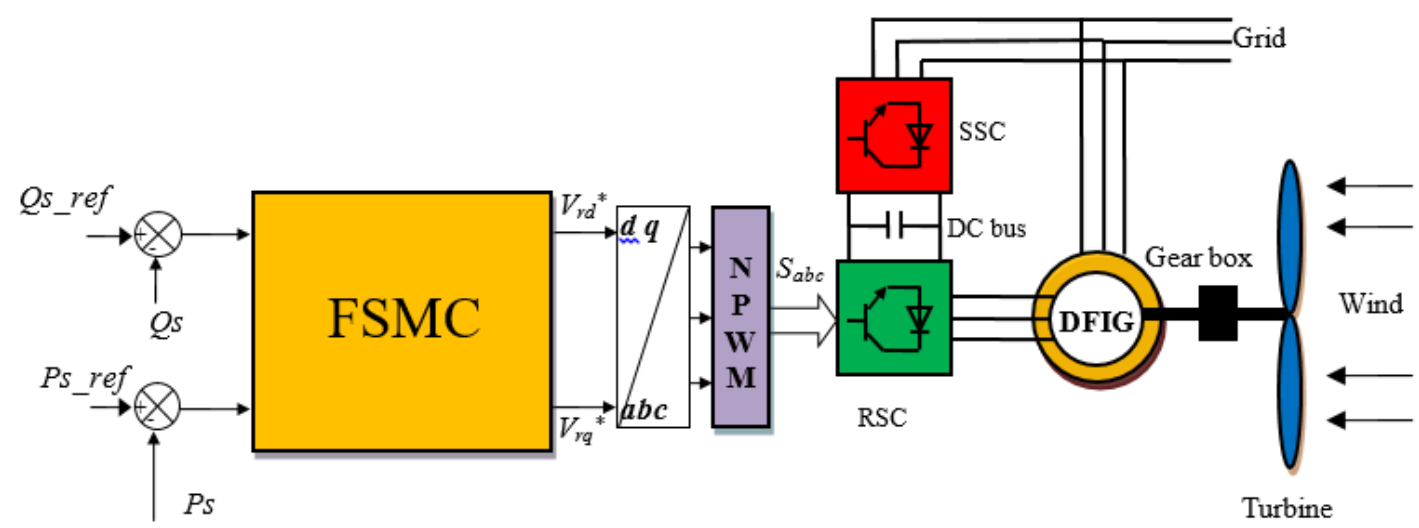

Figure 15. FSMC control of a DFIG using NPWM strategy

\subsection{Reference tracking test}

Figures 16-18 show the obtained simulation results. For the proposed strategies, the stator reactive and active power tracks almost perfectly their references values. Moreover, the FSMC-NSVPWM strategy reduced the powers ripples compared to the FSMC-NPWM control can be seen in Figures 19 and 20. The electromagnetic torque of the FSMC-NSVPWM control has low ripples compared to FSMC-NPWM, shown in Figure 21. Figures 22 and 23 shows the harmonic spectrums of one phase stator current of the DFIG obtained using fast fourier transform technique for FSMC-NPWM and FSMC-NSVPWM one respectively. It can be clear observed that the total harmonic distortion (THD) is reduced for FSMC- NSVPWM control method $(\mathrm{THD}=0.09 \%)$ when compared to NSMC-PWM $(\mathrm{THD}=0.10 \%)$. It is clear from the results that the FSMC with two-level NSVPWM strategy has satisfied performance.

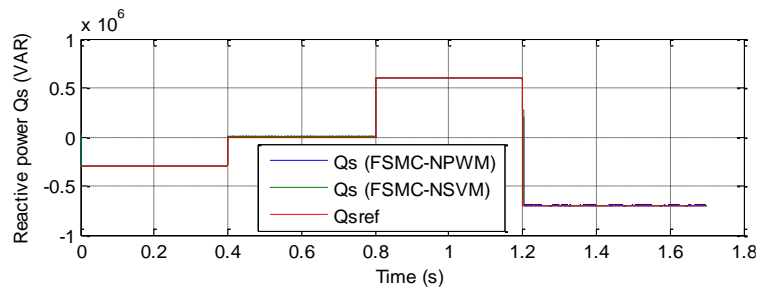

Figure 16. Reactive power (RTT)

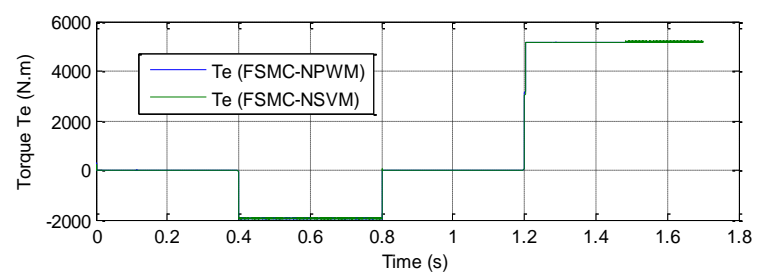

Figure 18. Electromagnetic torque (RTT)

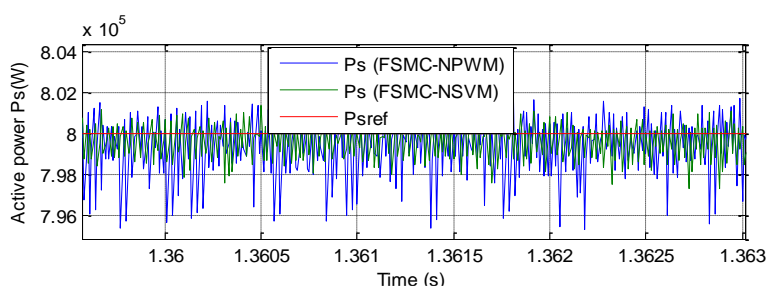

Figure 20. Zoom in the active power (RTT)

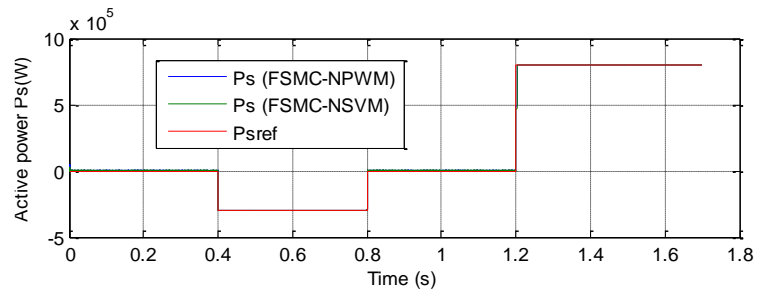

Figure 17. Active power (RTT)

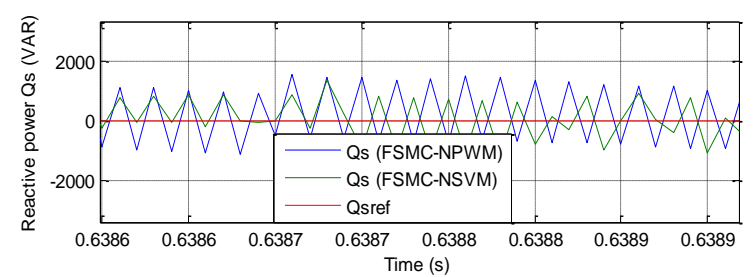

Figure 19. Zoom in the reactive power (RTT)

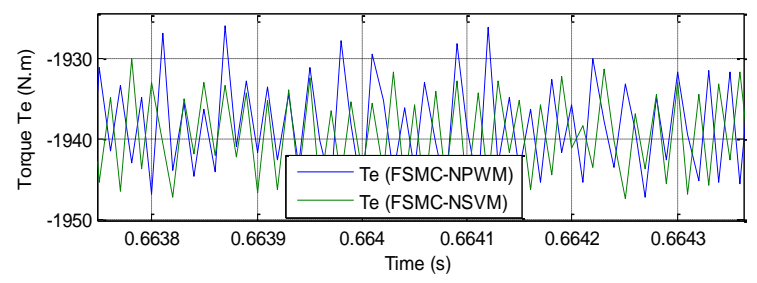

Figure 21. Zoom in the electromagnetic torque (RTT) 

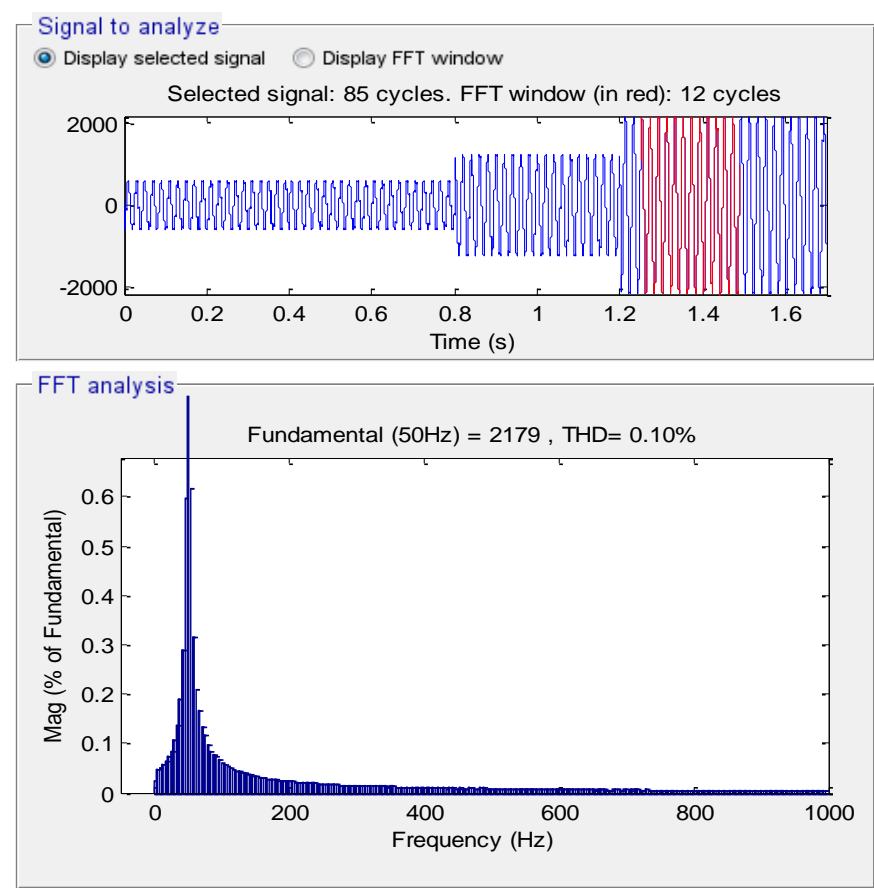

Figure 22. THD of one phase rotor current for FSMC-NPWM control (RTT)
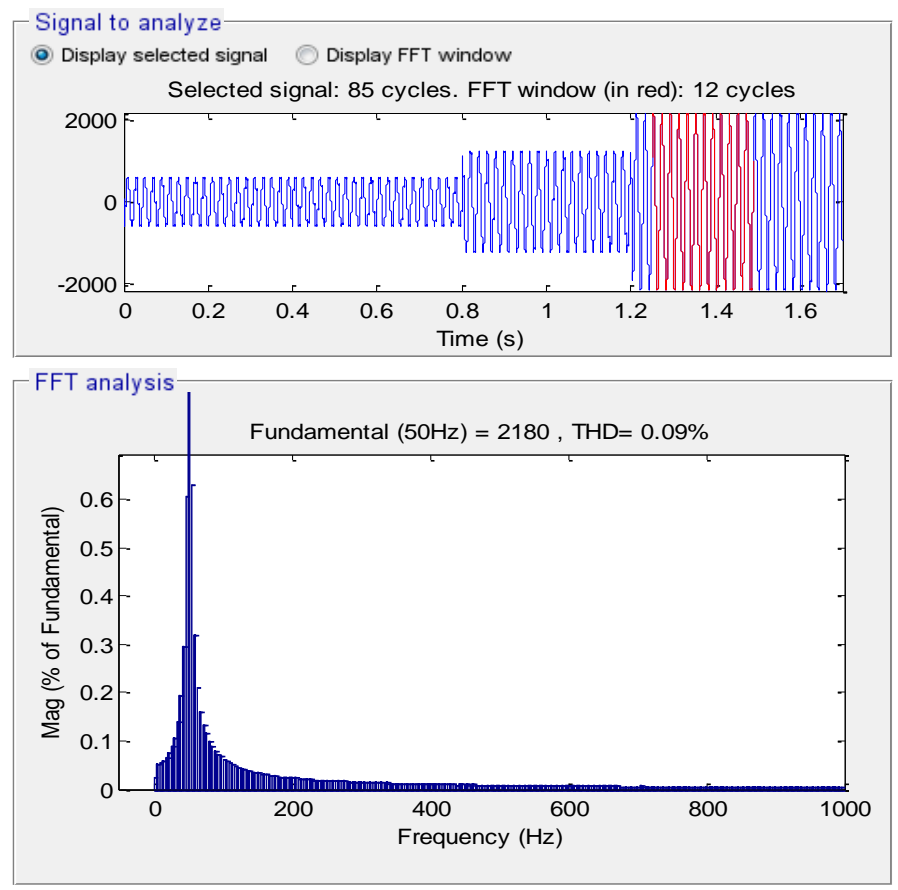

Figure 23. THD of one phase rotor current for FSMC- NSVPWM control (RTT)

\subsection{Robustness test}

In order to examine the robustness of the proposed commands schemes, the nominal value of the $R_{r}$ and $R_{S}$ is multiplied by 2 , the values of inductances $L_{s}, \mathrm{M}$, and $L_{r}$ are multiplied by 0.5 . Simulation results are presented in Figures 24-26. As it's shown by these Figures, these variations present a clear effect on the electromagnetic torque, stator reactive power and active power. However the effect appears more important for the FSMC-NPWM compared to FSMC-NSVPWM strategy, see Figures 27-29. Thus it can be concluded that the FSMC-NSVPWM control is more robust than the FSMC-NPWM control scheme. 


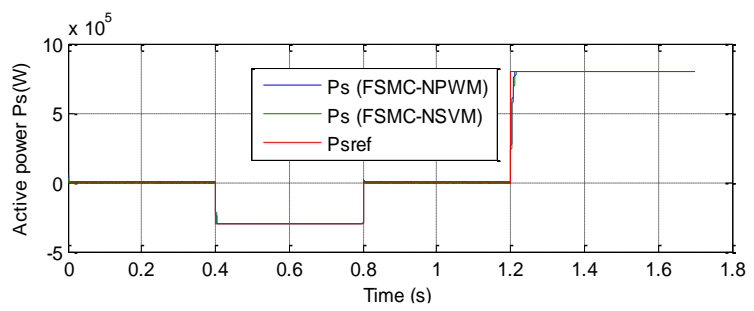

Figure 24. Active power (RT)

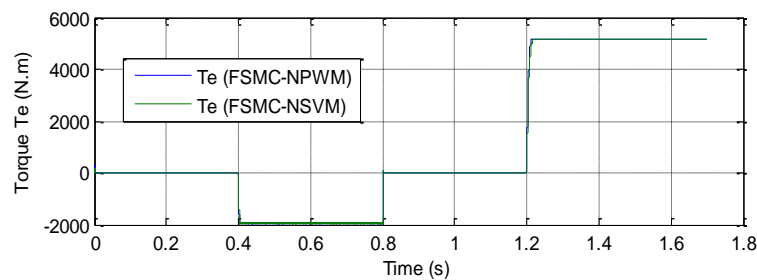

Figure 26. Electromagnetic torque (RT)

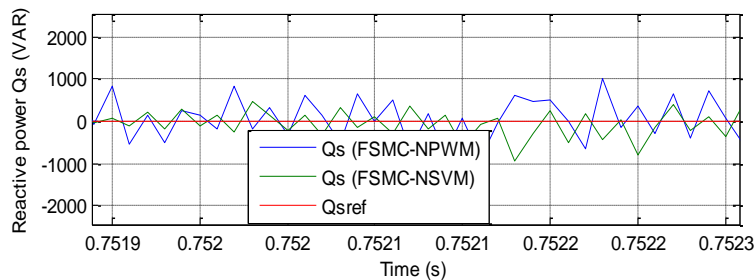

Figure 28. Zoom in the reactive power (RT)

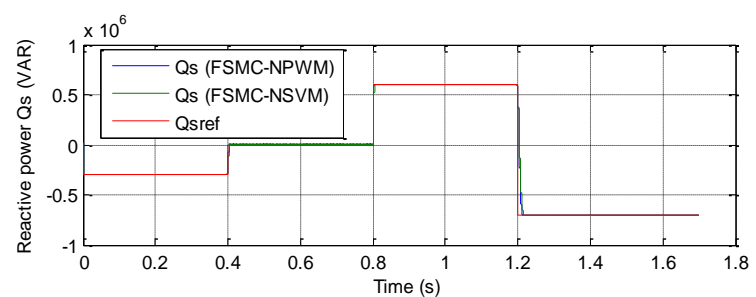

Figure 25. Reactive power (RT)

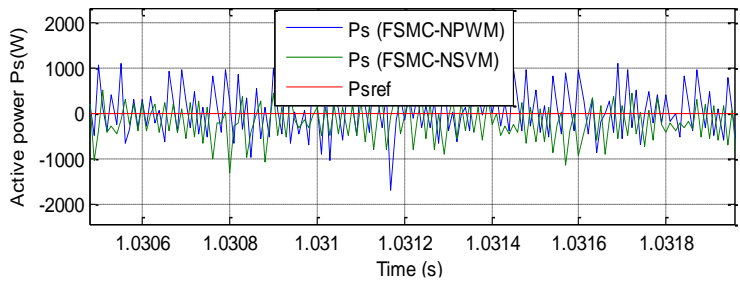

Figure 27. Zoom in the active power (RT)

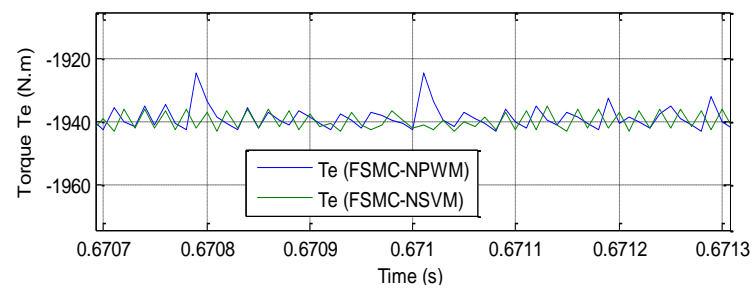

Figure 29. Zoom in the electromagnetic torque (RT)

\section{CONCLUSION}

This paper presents simulation of FSMC strategy for reactive and active power control of a DFIGbased wind turbine systems, using the modulation technique of the two-level NPWM and NSVPWM strategy. With results obtained from simulation, it is clear that for the same operation condition, the $1.5 \mathrm{MW}$ DFIG with FSMC control using two-level NSVPWM strategy had better performance than the two-level NPWM strategy and that is clear in the ripples of active and reactive powers which the use of the two-level NSVPWM strategy, it is minimized of powers ripples more than two-level NPWM strategy.

\section{APPENDIX}

\section{Design of SMC control}

The SMC control does not need accurate mathematical models like classical controllers. We choose the error between the reference stator energies and measured as sliding mode surfaces, so we can write the following expression:

$$
\left\{\begin{array}{l}
S_{p}=P_{s_{r e f}}-P_{s} \\
S_{q}=Q_{s_{r e f}}-Q_{s}
\end{array}\right.
$$

where $\mathrm{P}_{\mathrm{s} \text { ref }}$ and $\mathrm{Q}_{\mathrm{s} \text { ref }}$ are the expected stator active and reactive power reference. The first order derivate of (7), gives:

$$
\left\{\begin{array}{l}
\dot{S}_{p}=\dot{P}_{s r e f}-\dot{P}_{s} \\
\dot{S}_{q}=\dot{Q}_{s r e f}-\dot{Q}_{s}
\end{array}\right.
$$




$$
\left\{\begin{array}{c}
\dot{S}_{p}=\dot{P}_{s_{r e f}}-\frac{V_{s} \cdot M}{L_{S}} \dot{I}_{q r}+\frac{V_{s}^{2}}{R_{s}}-\frac{w_{s}^{2} \psi_{s}^{2}}{R_{s}} \\
\dot{S}_{q}=\dot{Q}_{s_{r e f}}+\frac{V_{s} M}{L_{s}} \dot{I}_{d r}-\frac{w_{s} \psi_{s}^{2}}{L_{s}}
\end{array}\right.
$$

The equivalent control vector $\mathrm{V}^{\mathrm{eq}}$ can express by:

$$
\left\{\begin{array}{l}
V_{d r}^{e q}=R_{r} \cdot I_{d r}-L_{s} \frac{\left(L_{r}-\frac{M^{2}}{M L_{s} w_{s}}\right)}{Q_{s r e f}}-g \cdot w_{s} \cdot\left(L_{r}-\frac{M^{2}}{L_{s}}\right) \cdot I_{q r}+\frac{\left(L_{r}-\frac{M^{2}}{L_{s}}\right)}{M} w_{s} \\
V_{q r}^{e q}=R_{r} \cdot I_{q r}+\frac{L_{s}}{V_{s} M} \dot{P}_{s_{r e f}}-g \cdot w_{s} \cdot\left(L_{r}-\frac{M^{2}}{L_{s}}\right) \cdot I_{d r}+g \cdot \frac{M \cdot V_{s}}{L_{s}}
\end{array}\right.
$$

To obtain good performances, dynamic and a commutation around the surface, the control vector is imposed as follows:

$$
V_{d q}=V_{d q}^{e q}+V_{d q}^{n}
$$

$V_{d q}^{n}$ is the saturation function defined by:

$$
V_{d q}^{n}=-K . \operatorname{sat}\left(S_{d q}\right)
$$

where $K$ determine the ability of overcoming the chattering.

The SMC will exist only if the following condition is met:

$$
S . \dot{S} \prec 0
$$

The block diagram of the conventional SMC strategy is shown in Figure 30.

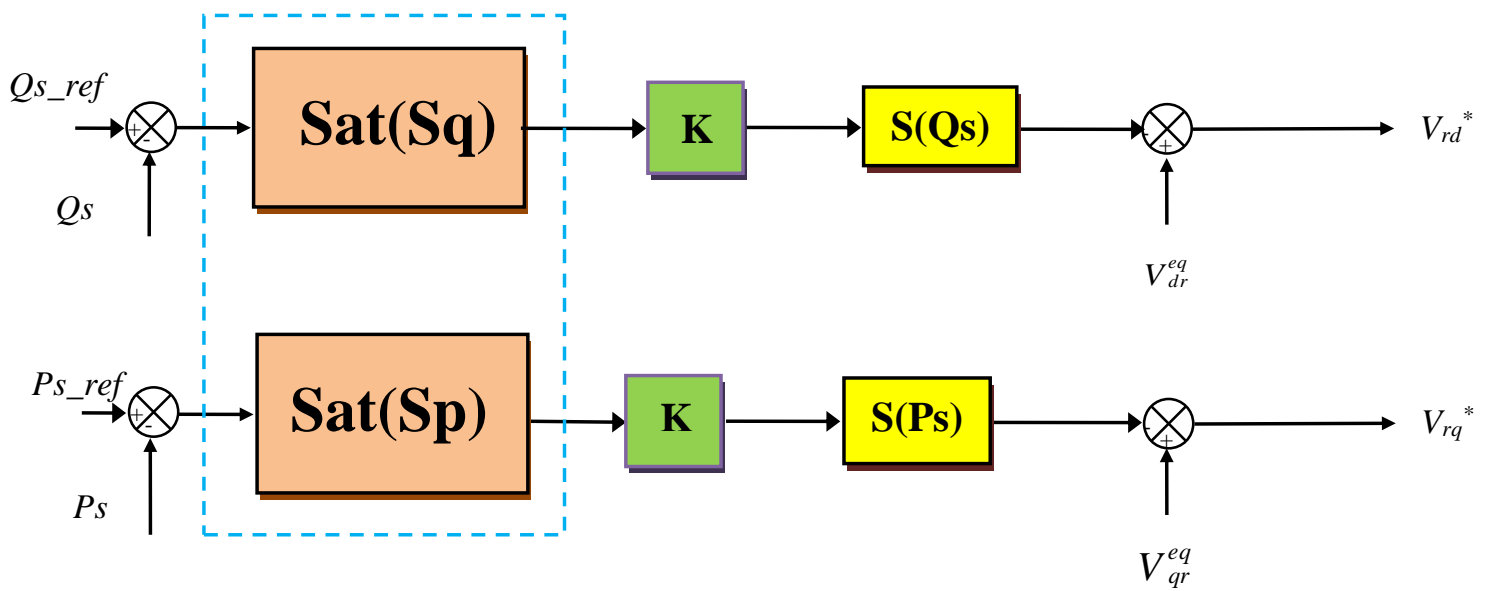

Figure 30. Block diagram of SMC strategy

\section{REFERENCES}

[1] H. Benbouhenni, "Sliding mode with neural network regulator for DFIG using two-level NPWM inverter," Iranian Journal of Electrical and Electronic Engineering, vol. 15, no. 3, pp. 411-419, 2019.

[2] H. Benbouhenni, "FPWM technique based based converter for IM drives," Journal Acta Electrotehica, vol. 19, no. 1, pp. 32-41, 2019. 
[3] Y. Bekakra and D. Ben Attous, "Comparison study between SVM and PWM inverter in sliding mode control of active and reactive power control of a DFIG for variable speed wind energy," International Journal of Renewable Energy Research, vol. 2, no. 3, pp. 471-476, 2012.

[4] D. Kanimozhi, S. Saravanan, and S. Satheeshkumar, "Analysis of doubly fed induction generator connected matrix converter in wind farm," Int. Journal of Engineering Research \& Technology, vol. 2, pp. 3981-3988, 2013.

[5] F. Bishuang, T. Guanzheng, and F. Shaosheng, "Comparison of three different 2-Dspace vector PWM algorithms and their FPGA implementations," Journal of Power Technologies, vol. 94, no. 3, pp. 176-189, 2014.

[6] M. Gaballah, M. El-Bardini, S. Sharaf, and M. Mabrouk, "Implementation of space vector-PWM for driving two level voltage source inverters," Journal of Engineering Sciences, vol. 39, no. 4, pp. 871-884, 2011.

[7] H. Obdan and M. C. Ozkilic, "Performance comparison of 2-level and 3-level converters in a wind energy conversion system," Rev. Roum. Sci. Techn.-Electrotechn. et Energ, vol. 61, no. 4, pp. 388-393, 2016.

[8] H. Benbouhenni, "Comparative study between NSVM and FSVM strategy for a DFIG-based wind turbine system controlled by neuro-second order sliding mode," Majlesi J. of Mechatronic Systems, vol. 7, no. 1, pp. 33-43, 2018.

[9] H. Benbouhenni, Z. Boudjema, and A. Belaidi, "Neuro-second order sliding mode control of a DFIG supplied by a two-level NSVM inverter for wind turbine system," Iranian Journal of Electrical and Electronic Engineering, vol. 14, no. 3, pp.362-373, 2018.

[10] H. Benbouhenni, Z. Boudjema, and A. Belaidi, "A comparative study between four-level NSVM and three-level NSVM technique for a DFIG-based WECSs controlled by indirect vector control," Carpathian Journal of Electronic and Computer Engineering, vol. 11, no. 2, pp.13-19, 2018.

[11] H. Benbouhenni, Z. Boudjema, and A. Belaidi, "Indirect vector control of a DFIG supplied by a two-level FSVM inverter for wind turbine system," Majlesi Journal of Electrical Engineering, vol. 13, no. 1, pp. 45-54, 2019.

[12] H. Benbouhenni, Z. Boudjema, and A. Belaidi, "Using three-level Fuzzy space vector modulation method to improve indirect vector control strategy of a DFIG based wind energy conversion systems," International Journal Of Smart Grid, vol. 2, no. 3, pp.155-171, 2018.

[13] H. Benbouhenni, Z. Boudjema, and A. Belaidi, "DFIG-based wind turbine system using three-level neural space vector modulation technique," Majlesi Journal of Mechatronic Systems, vol. 7, no. 2, pp. 35-45, 2018.

[14] H. Benbouhenni, Z. Boudjema, and A. Belaidi, "DFIG-based wind turbine system using four-level FSVM strategy," Majlesi Journal of Energy Management, vol. 6, no. 3, pp. 7-19, 2017.

[15] H. Benbouhenni, "Comparative study between different vector control methods applied to DFIG wind turbines," Majlesi Journal of Mechatronic Systems, vol. 7, no. 4, pp. 15-23, 2018.

[16] H. Benbouhenni, Z. Boudjema, and A. Belaidi, "Direct vector control of a DFIG supplied by an intelligent SVM inverter for wind turbine system," Iranian J. of Electrical and Electronic Eng., vol. 15, no. 1, pp. 45-55, 2019.

[17] Z. Boudjema, R. Taleb, Y. Djerriri, and A. Yahdou, "A novel direct torque control using second order continuous sliding mode of a doubly fed induction generator for a wind energy conversion system," Turkish Journal of Electrical Engineering \& Computer Sciences, vol. 25, pp. 965-975, 2017.

[18] H. Benbouhenni, "Comparative study between direct vector control and fuzzy sliding mode controller in three-level space vector modulation inverter of reactive and active power command of DFIG-based wind turbine systems," International Journal Of Smart Grid, vol. 2, no. 4, pp. 188-196, 2018.

[19] N. Khemiri, A. Khedher, and M. F. Mimouni, "Wind energy conversion system using DFIG controlled by backstepping and sliding mode strategies," Int. J. of Renewable Energy Research, vol. 2, no. 3, pp. 421-434, 2012.

[20] M. Adjoudj, M. Abid, A. Aissaoui, Y. Ramdani, and H. Bounoua, "Sliding mode control of a doubly fed induction generator for wind turbines," Rev. Roum. Sci. Techn.-Electrotechn. Et Energ, vol. 56, no. 1, pp. 15-24, 2011.

[21] H. Moradi and V. J. Majd, "A dissipative integral sliding mode control redesign method for uncertain nonlinear switched systems," Iranian Journal of Electrical \& Electronic Engineering, vol. 11, no. 4, pp. 310-318, 2015.

[22] S. E. Ardjoun and M. Abid, "Fuzzy sliding mode control applied to a doubly fed induction generator for wind turbines," Turkish Journal of Electrical Engineering \& Computer Sciences, vol. 23, pp. 1673-1686, 2015.

[23] Z. Boudjema, A. Meroufel, Y. Djerriri, and E. Bounadja, "Fuzzy sliding mode control of a doubly fed induction generator for wind energy conversion," Carpathian J. of Electronic and Compt. Eng., vol. 6, no. 2, pp. 7-14, 2013.

[24] H. Benbouhenni, "A comparison study between fuzzy PWM and SVM inverter in NSMC control of stator active and reactive power control of a DFIG based wind turbine systems," International Journal of Applied Power Engineering, vol. 8, No. 1, pp. 78-92, 2019.

[25] D. Kairous and R. Wamkeue, "DFIG-based fuzzy sliding-mode control of WECS with a flywheel energy storage," Electr. Power Syst. Res., vol. 93, pp. 16-23, 2012.

[26] V. I. Utkin, "Sliding mode control design principles and applications to electric drives," in IEEE Transactions on Industrial Electronics, vol. 40, no. 1, pp. 23-36, Feb. 1993.

[27] M. Hasni, Z. Mancer, S. Mekhtoub and S. Bacha, "Parametric identification of the doubly fed induction machine," Energy Procedia, vol. 18, pp. 177-186, 2012.

[28] E. Bounadja, A. Djahbar, and Z. Boudjema, "Variable structure control of a doubly fed induction generator for wind energy conversion systems," Energy Procedia, vol. 50, pp. 999-1007, 2014.

[29] H. Benbouhenni, Z. Boudjema and A. Belaidi, "A novel Matlab/Simulink model of DFIG drive using NSMC method with NSVM strategy," International Journal of Applied Power Engineering, vol. 8, no. 3, pp. 221-233, 2019.

[30] H. Benbouhenni, "Neuro-sconde order sliding mode field oriented control for DFIG based wind turbine," International Journal Of Smart Grid, vol. 2, no. 4, pp. 209-217, 2018.

[31] H. Benbouhenni, "Seven-level direct torque control of induction motor based on artificial neural networks with regulation speed using fuzzy PI controller," Iranian Journal of Electrical and Electronic Engineering, vol.14, no.1, pp.85-94, 2018. 
[32] M. N. E. Mohd Idrus, and K. S. Chia, "Artificial neural network and partial least square in predicting blood hemoglobin using near-infrared spectrum," Indonesian Journal of Electrical Engineering and Computer Science, vol. 16, no. 2, pp.701-708, 2019.

[33] M. Benkahla, R. Taleb, and Z. Boudjema, "Comparative study of robust control strategies for a DFIG-based wind turbine," International Journal of Advanced Computer Science and Applications, vol. 7, no. 2, pp. 455-462, 2016.

[34] H. Benbouhenni, "Fuzzy second order sliding mode controller based on three-level fuzzy space vector modulation of a DFIG for wind energy conversion systems," Majlesi J. of Mechatronic Systems, vol. 7, no. 3, pp.17-26, 2018.

[35] M. S. Merzoug, H. Benalla, and L. Louze, "Sliding mode control (SMC) of permanent magnet synchronous generators (PMSG)," Energy Procedia, vol. 18, pp. 43-52, 2012.

[36] Z. Boudjema, A. Meroufel, and A. Amari, "Robust control of a doubly fed induction generator (DFIG) fed by a direct AC-AC converter," Przeglad Elektrotechniczny, vol. 12, no. 12, pp. 213-221, 2012.

[37] F. Chabni, R. Taleb, A. Benbouali, and M. A. Bouthiba, "The application of fuzzy control in water tank level using arduino," International Journal of Advanced Computer Science and Applications, vol. 7, no. 4, pp. 261-265, 2016.

\section{BIOGRAPHIES OF AUTHORS}
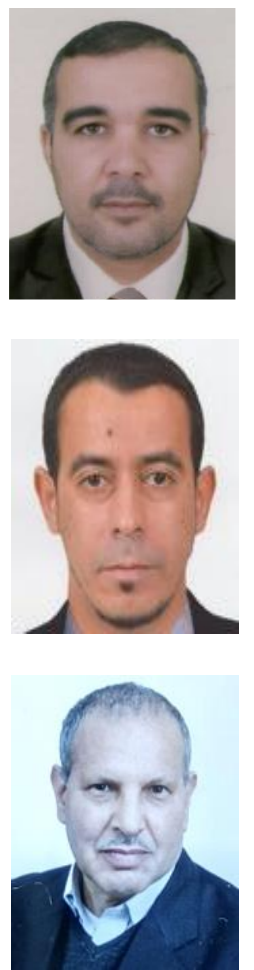

H. Benbouhenni was born in chlef, Algeria. $\mathrm{He}$ is a $\mathrm{PhD}$ student in the Department of Electrical Engineering, ENPO-MA, Oran, Algeria. He received M.A. degree of automatic and informatique industrial in 2017. His research activities include the application of robust control in the wind turbine power systems.

E-mail: habib0264@gmail.com

Zinelaabidine Boudjema was born in Algeria in 1983. He is teacher in University of Chlef, Algeria. He received M.S. degree in electrical engineering from ENP of Oran, Algeria in 2010. He received a PhD in electrical engineering from University of Sidi Belabes, Algeria 2015. His research activities include the study and application of robust control in the windsolar power systems.

E-mail: boudjemaa1983@yahoo.fr

Abdelkader Belaidi is professor at the National Polytechnic High School - Maurice Audin, Oran, Algeria. He obtained his Ph.D in physics at the University of East Anglia-UK in 1980. His current fields of interest are nanotechnology, robototics and artificial intelligence.

E-mail: belaidiaek@gmail.com 